\title{
The synthetic peptide P111-136 derived from the C-terminal domain of heparin affin regulatory peptide inhibits tumour growth of prostate cancer PC-3 cells
}

Yamina Hamma-Kourbali', Oya Bermek ${ }^{1}$, Isabelle Bernard-Pierrot ${ }^{1,3}$, Racha Karaky², Dominique Martel-Renoir ${ }^{2}$, Sophie Frechault ${ }^{1}$, José Courty ${ }^{1}$ and Jean Delbé ${ }^{* *}$

\begin{abstract}
Background: Heparin affin regulatory peptide (HARP), also called pleiotrophin, is a heparin-binding, secreted factor that is overexpressed in several tumours and associated to tumour growth, angiogenesis and metastasis. The Cterminus part of HARP composed of amino acids 111 to 136 is particularly involved in its biological activities and we previously established that a synthetic peptide composed of the same amino acids (P111-136) was capable of inhibiting the biological activities of HARP. Here we evaluate the ability of P111-136 to inhibit in vitro and in vivo the growth of a human tumour cell line PC-3 which possess an HARP autocrine loop.

Methods: A total lysate of PC-3 cells was incubated with biotinylated P111-136 and pulled down for the presence of the HARP receptors in Western blot. In vitro, the P111-136 effect on HARP autocrine loop in PC-3 cells was determined by colony formation in soft agar. In vivo, PC-3 cells were inoculated in the flank of athymic nude mice. Animals were treated with P111-136 (5 mg/kg/day) for 25 days. Tumour volume was evaluated during the treatment. After the animal sacrifice, the tumour apoptosis and associated angiogenesis were evaluated by immunohistochemistry. In vivo anti-angiogenic effect was confirmed using a mouse Matrige| ${ }^{\mathrm{TM}}$ plug assay.

Results: Using pull down experiments, we identified the HARP receptors RPTP $/ \zeta$, ALK and nucleolin as P111-136 binding proteins. In vitro, P111-136 inhibits dose-dependently PC-3 cell colony formation. Treatment with P111-136 inhibits significantly the $\mathrm{PC}-3$ tumour growth in the xenograft model as well as tumour angiogenesis. The angiostatic effect of P111-136 on HARP was also confirmed using an in vivo Matrige|TM plug assay in mice

Conclusions: Our results demonstrate that P111-136 strongly inhibits the mitogenic effect of HARP on in vitro and in vivo growth of $\mathrm{PC}-3$ cells. This inhibition could be linked to a direct or indirect binding of this peptide to the HARP receptors (ALK, RPTP $\beta / \zeta$, nucleolin). In vivo, the P111-136 treatment significantly inhibits both the PC-3 tumour growth and the associated angiogenesis. Thus, P111-136 may be considered as an interesting pharmacological tool to interfere with tumour growth that has now to be evaluated in other cancer types.
\end{abstract}

\section{Background}

Prostate cancer is among the leading malignancies in men throughout much of the industrialized world and ranks second among causes of death from cancer. The lack of not enough effective treatments indicates a need

\footnotetext{
* Correspondence: delbe@univ-paris12.fr

'Laboratoire de Recherche sur la Croissance Cellulaire, la Réparation et la Régénération Tissulaires (CRRET), Université Paris Est Créteil, CNRS, avenue du Général de Gaulle, 94010 Créteil Cedex, France

Full list of author information is available at the end of the article
}

to develop novel treatment strategies targeting new molecules like growth factors. Epithelial-stromal interactions play a pivotal role in the functional integrity of the normal prostate adult gland [1]. This physiological process requires complex interactions between peptide growth factors and growth modulators, which may be regulated either by androgens or by other factors [2,3]. Any imbalance in these interactions, such as up or down regulation of growth factors or their receptors or

\section{Biomed Central}


a switch from paracrine to autocrine mediation of growth-factor pathways leads to prostate tumour progression. Among the growth-factor families involved in prostate-cancer progression, Transforming Growth Factor-beta (TGF $\beta$ ), Fibroblast Growth Factors (FGFs), Epidermal Growth Factor (EGF) and heparin affin regulatory peptide (HARP) were reported to play a prominent role [3]. HARP, also called pleiotrophin is a 136 amino acids secreted polypeptide that forms with the protein midkine (MK) a specific family among the heparin-binding growth factors [4]. During embryonic development, HARP is expressed in tissues originating in the mesoderm and neuroectoderm, suggesting a role in epithelium-mesenchyme interactions and in neuronal migration. In adults, HARP expression is limited except at sites such as the mammary gland and uterus associated with reproductive angiogenesis [2]. Furthermore, HARP overexpression has been documented in pathologies associated with cell proliferation and angiogenesis, such as rheumatoid arthritis [5] and tumour growth [6]. HARP has been shown to exert oncogenic potential by transforming various cell lines upon HARP cDNA transfection $[7,8]$. In addition, HARP has been shown to play a key role in prostate cancer. Thus, plasma HARP levels were elevated in patients with prostate cancer $[9,10]$. Furthermore, HARP protein was associated with epithelial cells in prostate cancer but not in normal prostate tissue and the mRNAs were located in the stromal compartment, suggesting a paracrine mechanism of action for HARP [11]. In vitro, HARP overexpression in normal prostate epithelial PNT-1A cells induced both anchorage-independent and anchorage-dependent growth at low serum concentrations. HARP was also mitogenic for PC-3, LNCaP, and DU145 cell lines [11]. The growthpromoting effect of HARP on prostate cancer cells was also confirmed using an antisense strategy, which established HARP as an important autocrine growth factor for the LNCaP prostate-cancer cell line and as a paracrine factor involved in angiogenesis [12].

Two transmembrane proteins with intracellular catalytic domains have been described as HARP receptors: the receptor-type protein tyrosine phosphatase beta/zeta (RPTP $\beta / \zeta$ ) and the anaplastic lymphoma kinase (ALK) receptor. The mitogenic and anti-apoptotic activities of HARP were initially linked to the high-affinity tyrosine kinase receptor ALK in a process mediated by the phosphatidylinositol 3-kinase and MAP kinase signaling pathways [13]. ALK was first identified as a constitutively active, oncogenic, chimeric nucleophosmin-ALK fusion protein [14]. Like HARP, ALK is expressed during normal embryonic development in the similar pattern [15]; however it is also overexpressed in different several human cancers $[16,17]$. The neurite outgrowth, the cell migration and adhesion activities of HARP were initially associated with the chondroitin sulfate proteoglycan RPTP $\beta / \zeta[18,19]$. HARP was shown to signal through enforced dimerization of RPTP $\beta / \zeta$ which, in turn, results in a loss of the RPTP $\beta / \zeta$ catalytic tyrosine phosphatase activity. Inactivation of RPTP $\beta / \zeta$ by HARP interaction increased tyrosine phosphorylation of each of the substrates of RPTP $\beta / \zeta$ leading to modification of the cytoskeleton network via the $\beta$-catenin, p190RhoGAP, and $\beta$-adducin signaling pathway [20-23]. However, it has also been recently demonstrated that ALK is activated through the HARP/RPTP $\beta / \zeta$ pathway, thus introducing a unique "alternative mechanism of tyrosine kinase receptor activation" [24].

HARP consists of two beta-sheet domains (N- and CTSR) containing thrombospondin-I repeats, which are flanked by flexible lysine-rich $\mathrm{N}$ - and C-terminal tails. Previous studies suggested that the C-TSR domain and the C-terminus regions of HARP were particularly involved in the biological activities of HARP [25-28]. Thus, the C-terminus, composed of amino acids 111 through 136, was involved in the binding of HARP to the ALK receptor $[25,26]$. In these previous studies, mutant HARP protein lacking amino acids 111 through 136 acted as a dominant negative effector of HARP mitogenic, angiogenic, and transforming activities. The synthetic peptide composed of the deleted amino-acid segment P111-136 inhibited HARP mitogenic activity in NIH-3T3, the growth of MDA-MB 231 cells in soft agar and competed with HARP for binding to the extracellular domain of ALK receptor [26] thus representing an interesting pharmacological tool.

The objective of this study was to further complete our investigations on P111-136 and to evaluate its growth inhibitory activity both in vitro and in vivo on the human prostatic adenocarcinoma cell line PC-3.

\section{Methods \\ Materials}

Culture mediums, foetal calf serum (FCS), G418 and rabbit antibody to human ALK were supplied by Invitrogen (Cergy Pontoise, France). Heparin-Sepharose, streptavidin-Sepharose gels and Mono-STM column were from GE HealthCare (Orsay, France), BM ChemiLuminescence from Roche Diagnostic (Meylan, France). Superblocker ${ }^{\mathrm{TM}}$ solution was purchased from PerbioPierce (Montluçon, France). Immobilon-P from Millipore Corp (Saint-Quentin en Yvelines, France). Goat antibody to human HARP and rabbit antibody to human $\mathrm{RPTP} \beta / \zeta$ were from R\&D (Lille, France). Monoclonal antibody to human nucleolin was from Santa Cruz biotechnology (Montrouge, France), goat antimouse CD31 (PECAM) polyclonal antibody and Matrigel $^{\mathrm{TM}}$ were from BD Pharmingen Biosciences (le Pont de Claix, France). Horseradish peroxidase-conjugated rabbit 
anti-goat IgG and goat anti-rabbit IgG were purchased from Jackson (Montluçon, France). Taxol ${ }^{\circledR}$ was purshased from Sigma Aldrich (Saint Quentin Fallavier, France). Synthetic P111-136 (KLTKPKPQAESKKKKKE GKKQEKMLD) and biotinylated P111-136 (KLTKPKP QAESKKKKKEGKKQEKMLDK-biot-CONH2) were obtained from Altergen (Schiltigheim, France). Recombinant human HARP was produced and purified from mammalian culture as described previously [25].

\section{Colony formation in soft agar}

PC-3 cells (ATCC, Manassas, VA, USA) were seeded at a density of $2 \times 10^{4}$ in triplicate into 12 -well plates containing agar and DMEM supplemented with 5\% FCS and various concentrations of either P111-136 peptide or antihuman HARP antibody or control non immune immunoglobulins. The compounds were added to the culture medium twice a week. After 12 days, colonies larger than 50 $\mu \mathrm{m}$ in diameter were counted using a phase-contrast microscope equipped with a reticule, in five fields in each of three wells. The assay was repeated at least twice.

\section{Pull down and Western blot analysis}

Cells were cultured in $100 \mathrm{~mm}$ Petri dishes in complete medium, then media were discarded and cells were washed 3 times with ice-cold PBS and lysed with $1 \mathrm{ml}$ of lysis buffer (50 mM HEPES, pH 7, $150 \mathrm{mM} \mathrm{NaCl}, 10 \mathrm{mM}$ EDTA, $1 \%$ TritonX-100, 1\% Nonidet P-40 (both v/v), $1 \mathrm{mM}$ phenylmethylsulfonyl fluoride, $1 \mathrm{mM}$ sodium orthovanadate, 5 $\mu \mathrm{g} / \mathrm{ml}$ aprotinin, and $5 \mu \mathrm{g} / \mathrm{ml}$ leupeptin). For pull down experiments, total proteins from cell lysate were precleaned with streptavidin-Sepharose beads for $1 \mathrm{~h}$ at room temperature followed by centrifugation at $10,000 \times \mathrm{g}$ for 5 min. The beads were collected by centrifugation and the supernatants were transferred to new microfuge tubes. After this precleaning step, supernatants were incubated overnight at $4^{\circ} \mathrm{C}$ with $5 \mu \mathrm{M}$ of biotinylated P111-136. A suspension of streptavidin-agarose beads in a volume of 80 $\mu \mathrm{l}$ was added. After $3 \mathrm{~h}$ incubation at $4{ }^{\circ} \mathrm{C}$, beads and bound proteins were collected by centrifugation $(10,000 \times$ $\mathrm{g}, 4^{\circ} \mathrm{C}$ ) and washed by centrifugation three times with icecold cell lysis buffer. The pellet was resuspended in $60 \mu \mathrm{l}$ of $2 \times$ SDS loading buffer (100 mM Tris- $\mathrm{HCl}$, pH 6.8, 4\% sodium dodecyl sulfate (w/v), 0.2\% (w/v) bromophenol blue, 20\% glycerol, $0.1 \mathrm{M}$ dithiothreitol), and kept at $4{ }^{\circ} \mathrm{C}$ until use. Western blot experiments were performed as described previously [29] using either anti RPTP $\beta / \zeta$, anti ALK or anti nucleolin antibodies. For the presence of HARP in PC-3 conditioned media, experiments were performed as described in previous studies [25].

\section{Tumour-cell inoculation to nude mice}

All in vivo experiments were approved by the appropriate ethics committee and conducted in compliance with
European Community directives. PC-3 carcinoma cells $\left(2 \times 10^{6}\right)$ were injected subcutaneously in the right flank of female athymic nude mice (Janvier, Le Genest St Isle, France). Two weeks after the injection, mouse had one palpable tumour about $60 \mathrm{~mm}^{3}$ in size. Groups of 5 mice were then given peritumoral injections of either $0.1 \mathrm{ml} \mathrm{PBS}$ alone, Taxol ${ }^{\circledR} 10 \mathrm{mg} / \mathrm{kg}$ twice a week, or P111-136 (5 mg/kg/day). Tumour size was determined twice a week by using callipers to measure the lengths of the two main axes, computing the corresponding radii (labelled $R 1$ and $R 2$, with $R 1<R 2$ ), and estimating tumour volume as $V=4 / 3 \times \pi \times R_{1}{ }^{2} \times R_{2}$, where $R_{1}$ is radius $1, R_{2}$ is radius 2 and $R_{1}<R_{2}$.

\section{Tissue preparation, immunohistochemical staining, and image analysis}

The PC-3 tumours were removed surgically then immediately quick-frozen in liquid nitrogen and fixed for $20 \mathrm{~min}$ in acetone at $4^{\circ} \mathrm{C}$. The $6-\mu \mathrm{m}$ sections were rehydrated in PBS then saturated with PBS containing $1 \%$ bovine serum albumin (BSA) and 2\% normal goat serum. Endogenous biotin was blocked using the Vector blocking kit (Vector Laboratories, Burlingame, CA). To visualize endothelial cells within the tumours, sections were incubated with goat anti-mouse CD31 polyclonal antibody for $1 \mathrm{~h}$ at room temperature. After two washes in PBS-Tween $20(0.2 \% \mathrm{v} / \mathrm{v})$, sections were incubated for $1 \mathrm{~h}$ at room temperature with biotinylated goat anti-rabbit IgG (Chemicon International Inc., Temecula, CA) in saturation buffer, followed by three washes and incubation with an avidin-biotinylated-alkaline phosphatase complex (Vector Laboratories). Alkaline phosphatase activity was revealed using the Vector red substrate (Vector Laboratories). Finally, the sections were counterstained with haematoxylin, washed with water, and cover slipped with mounting medium (Thermo Shandon, Pittsburgh, PA). For each CD31-labelled section, five microscopic fields containing exclusively viable tumour cells were randomly selected for analysis. Endothelial-cell density was expressed as the ratio of endothelial-cell area/total area examined $\times 100$. Mean values were then computed for untreated and treated tumours.

For tumour apoptosis analysis, immunohistochemistry was performed as previously described [30] using rabbit antibody raised against cleaved caspase 3 (Cell Signaling Technology, Saint-Quentin en Yvelines, France). Quantification of staining on histological slides was achieved using PIXCYT; a software package [31] designed by the Groupe Régional d'Etudes sur le Cancer, (Centre François Baclesse, Caen, France). This system combines a dedicated slide scanner and a computer-assisted image analysis. 


\section{In vivo mouse angiogenesis assay using the Matrige| ${ }^{\mathrm{TM}}$ plug model}

Swiss mice (Janvier, Le Genest St Isle, France) were injected subcutaneously with $0.3 \mathrm{ml}$ of growth-factor reduced Matrigel ${ }^{\mathrm{TM}}$ alone or containing either P111-136 $(1 \mu \mathrm{M})$, HARP $(5 \mathrm{nM})$, or a mixture of HARP and P111-136, (4 mice/group). The Matrigel ${ }^{\mathrm{TM}}$ rapidly formed a single, solid, gel plug. After 8 days, the skin was pulled back to expose the intact plug, which was dissected out, frozen in liquid nitrogen, and fixed with acetone. Matrigel ${ }^{\mathrm{TM}}$ plug sections $8 \mu \mathrm{m}$ in thickness were cut using a cryostat CM3050 (Leica Microsystems, Rueil, France) and stained with Gomori-Trichrome for microscopic observation. The area infiltrated by endothelial cells was then measured using an image analyser in six fields in each of three Matrigel ${ }^{\mathrm{TM}}$ plug sections from each mouse.

\section{Statistical analysis}

Unpaired Student's t test was used to assess differences between each group and the corresponding control group. Each experiment includes triplicate measurements for each condition. All results are reported as mean \pm SD determined from at least two independent experiments.

\section{Results}

Previously, it has been shown that peptide P111-136, structurally related to the C-terminal domain of HARP, inhibited specifically the mitogenic activity induced by HARP. It was also shown that P111-136 inhibited the in vitro growth of the human breast cancer cell line MDAMB 231 suggesting that P111-136 blocked the autocrine stimulation loop of HARP. In order to investigate more precisely the effect of P111-136 on tumour growth, including in vivo study, we investigated the effect of P111-136 on the androgen-independent prostate-cancer cell line PC-3 in which the presence of an autocrine loop of stimulation for this growth factor has been suggested [11,32].

\section{The peptide P111-136 inhibits the growth of PC-3 cells}

To confirm the HARP autocrine loop in supporting the growth of PC-3 cells, the presence of HARP in the conditioned media of PC-3 was firstly investigated by Western-blot. As shown in Figure 1A, a weak immunoreactive signal was observed in accord with previous observations [32]. Secondly, to prove that secreted HARP acted on PC-3 cells, the growth of these cells was studied in the soft agar colony-formation assay, a hallmark of malignant transformation, in absence or presence of a polyclonal anti-HARP antibody. As presented in Figure $1 \mathrm{~B}$, the polyclonal anti-HARP antibody induced a dose-dependent decrease in colony formation, whereas no effect has been observed using the idiotypic immunoglobulins as the control. These data confirmed the existence of an autocrine HARP-signalling loop for PC-3 cells and prompted us to investigate the effect of P111-136 on the proliferation of this cell line. P111-136 dose-dependently decreased colony formation (Figure $1 \mathrm{C})$. In the presence of $1 \mu \mathrm{M}$ P111-136, the colonies were smaller and $47 \%$ less numerous, compared to the control performed without peptide. In this respect, it is noteworthy that when tested in the same conditions, P122-131, which is another peptide derived from the Cterminal part of HARP inhibiting the growth of DU145 and LNCap prostate cancer cells [33], acted also on PC3 cells but in a lesser extent with only $22 \%$ inhibition for $1 \mu \mathrm{M}$ (data not shown).

\section{The peptide 111-136 inhibits the tumour growth of PC-3 cells in a mice xenograft model and the associated angiogenesis}

To further investigate the effect of P111-136 on HARPinduced PC-3 proliferation in vivo, athymic mice were subcutaneously injected with PC-3 cells, which consistently led to tumour development within 2 weeks. P111136 treatment was initiated at the end of the second week, when the tumours were well established, in order to simulate a curative treatment. Peritumoral injection of P111-136 (5 mg/kg/day) significantly reduced tumour growth as soon as the first week of treatment, compared to PBS used as the control (Figure 2A). After 25 days, tumour size was reduced by $61 \%$ in the P111-136 group. P111-136 treatment had no effect on body weight (data not shown) and induced no evidence of toxicity such as diarrhoea, infection, weakness, or lethargy. As expected, control treatment with $\mathrm{Taxol}^{\circledR}(10 \mathrm{mg} / \mathrm{kg}$ twice a week) strongly inhibited tumour growth, by $71 \%$ compared to PBS, after 25 days of treatment (Figure 2A). At the end of the study, the animals were sacrificed and tumour weight was determined. Both P111-136 and Taxol ${ }^{\circledR}$ significantly decreased tumour weight, by more than $65 \%$, compared with PBS, supporting the tumour-size data (Figure 2B). In order to investigate whether P111-136 treatment was associated with apoptosis of PC-3 cells, cleaved caspase 3 immunostaining was performed on tumour sections and quantified by software analysis. As shown in Figure 3, a two-fold increase in cleaved caspase 3 labelling was observed in tumour treated with P111-136 compare to the untreated tumours. In third investigation, to determine whether angiogenesis associated with tumour growth was also affected by P111136 treatment, we used CD31 immunostaining to quantify blood vessels. Compared to the untreated tumours (Figure 4A and 4C), peritumoral injections of P111-136 significantly decreased endothelial-cell density (Figure $4 \mathrm{~B}$ and $4 \mathrm{C})$. The mean percentage of endothelial cells in 


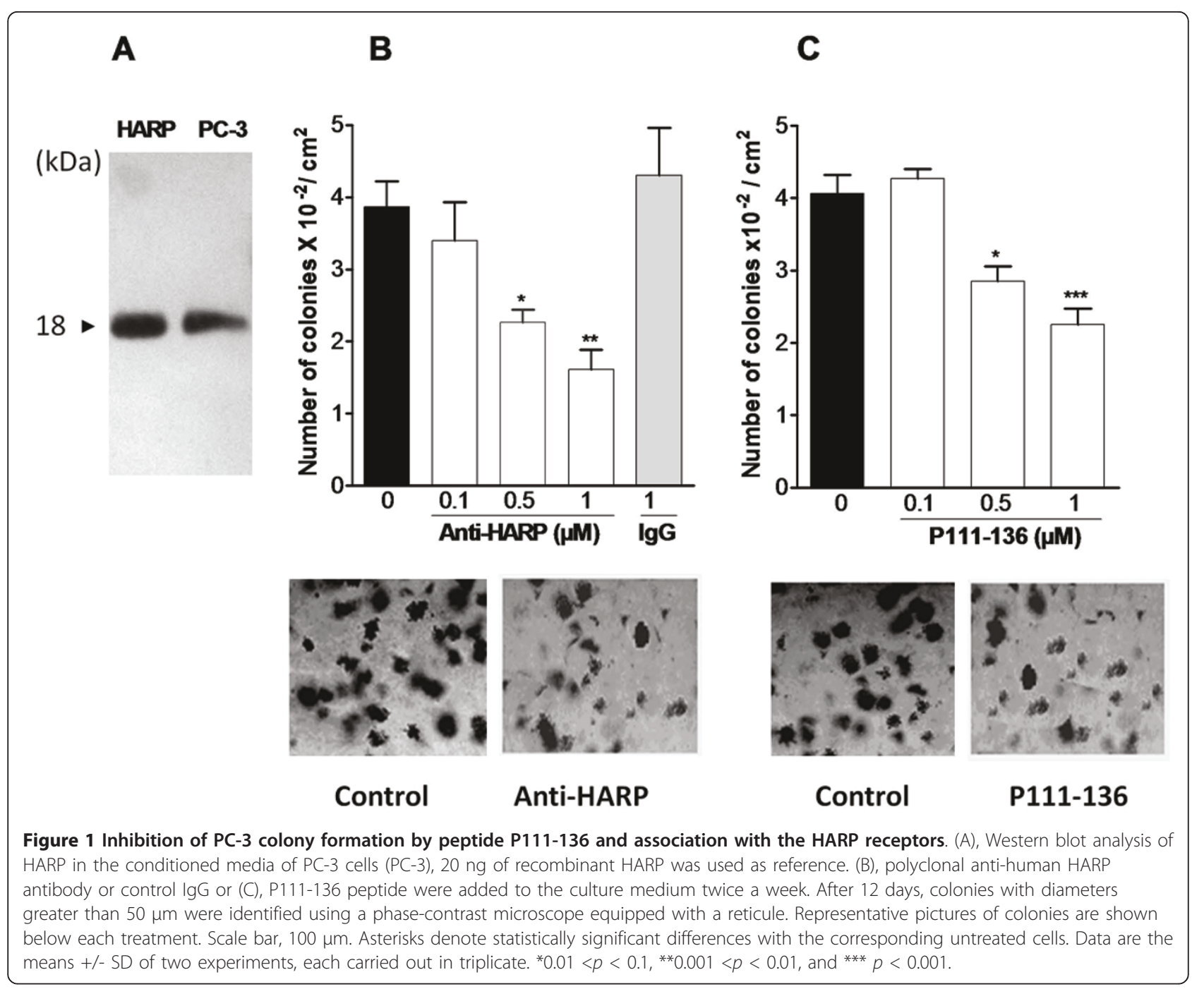

viable fields of tumours treated with $5 \mathrm{mg} / \mathrm{kg} /$ day of P111-136 was inhibited by $64 \%$ compared to the control tumour value ( $1.7 \pm 0.58$ vs. $4.8 \pm 2$, based on 25 fields in each of four tumours). These results suggested that the antitumoral effect of P111-136 could also act through direct inhibition of angiogenesis.

The peptide P111-136 inhibits the in vivo HARP-induced angiogenesis in a Matrigel ${ }^{\text {TM }}$ plug model

To investigate a direct effect of P111-136 on angiogenesis processes, we questioned whether the peptide inhibits the normal angiogenesis induced by HARP. This study was performed using in vivo mouse Matrigel ${ }^{\mathrm{TM}}$ plug assay. Incorporating $5 \mathrm{nM}$ of HARP into the Matrigel $^{\mathrm{TM}}$ resulted in a 3.7 -fold increase in endothelial-cell infiltration (Figure $5 \mathrm{C}$ and $5 \mathrm{E}$ ) compared to the untreated control plug, which contained only a few endothelial cells (Figure 5A and 5E). Addition of $1 \mu \mathrm{M}$ of P111-136 to the HARP-containing Matrigel $^{\mathrm{TM}}$ inhibited the effect of HARP on endothelial cell infiltration by $72 \%$ (Figure 5C, D and 5E). P111-136 had no effect on endothelial-cell infiltration using Matrigel $^{\mathrm{TM}}$ alone (Figure 5A, B and 5E). These data indicate that P111-136 inhibited the angiogenesis induced by HARP.

\section{P111-136 targets HARP interacting proteins}

Since P111-136 was previously described to compete with HARP for the binding of the ALK receptor [26] in a cell free assay, we then questioned whether P111-136 could bind in situ, using PC-3 cells, ALK and also the other molecular targets involved in the biological activity of HARP including RPTP $\beta / \zeta$ and nucleolin [34]. Pulldown experiments using biotinylated P111-136 (biotP111-136) and Western blot analysis were performed to answer this question. Firstly, Western blot analysis performed from whole-cell extracts of PC-3 indicated that this cell line expressed the 140 and $220 \mathrm{kDa}$ forms of ALK (Figure 6A), only the $240 \mathrm{kDa}$ form of RPTP $\beta / \zeta$ 

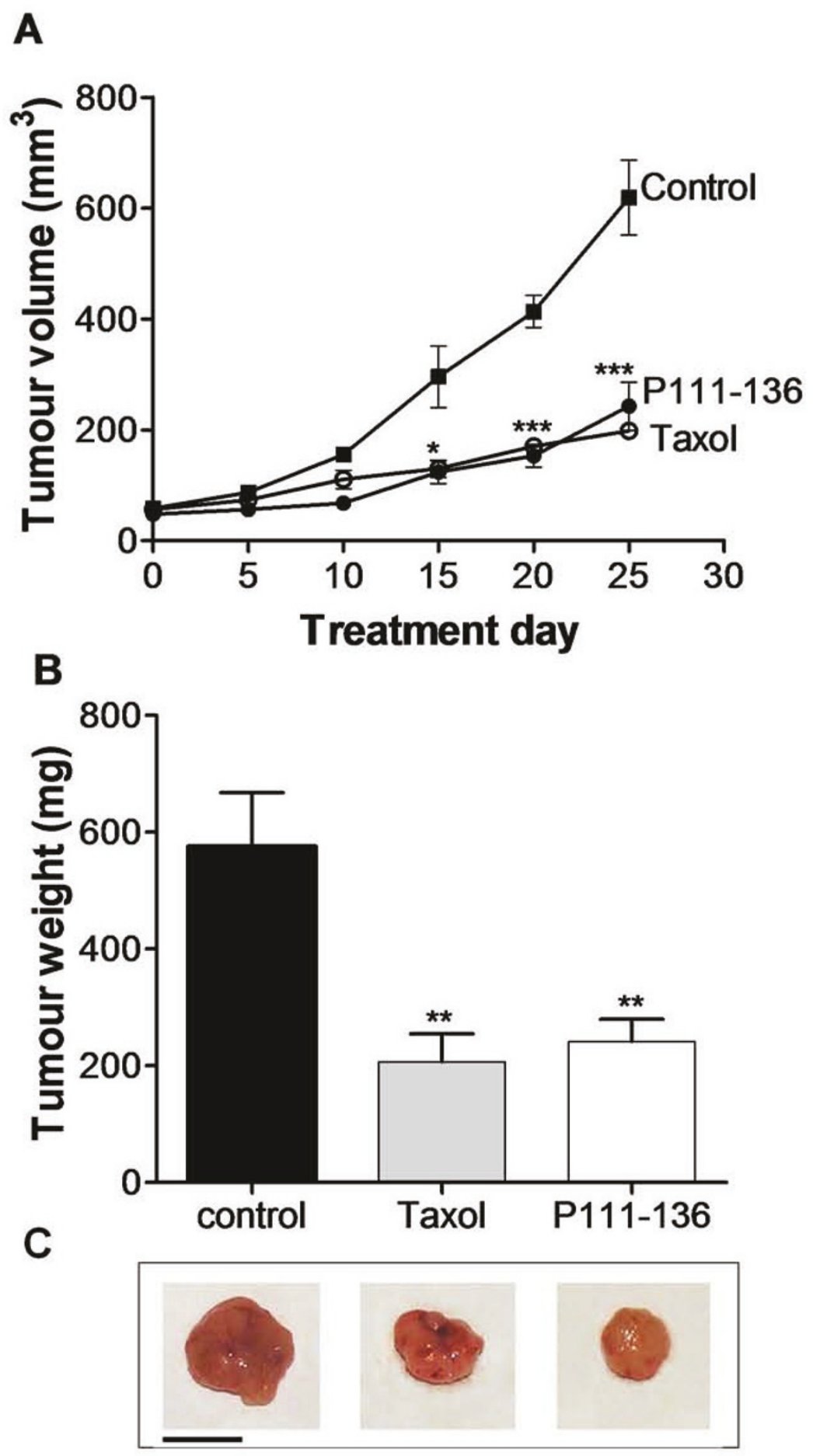

Figure 2 Inhibition of tumour growth by peptide P111-136. (A), Tumour-growth curves. PC-3 carcinoma cells $\left(2 \times 10^{6}\right)$ were injected subcutaneously into the right flanks of female nude mice. When tumour size was about $60 \mathrm{~mm}^{3}$, mice received peritumoral injections of P111136 (5 mg/kg/day) (black circle), Taxol ${ }^{\circledR}$ (10 mg/kg twice a week) (white circle), or PBS used as vehicle. (black square) for 25 days. Tumours were measured twice a week. (B), The mice were sacrificed 25 days after the cell injection; the tumours were excised and weighed. (C), A representative excised tumour of each group was represented below. Scale bar, $1 \mathrm{~cm}$. The data are mean tumour volume or weight $+/-$ SD obtained from 5 mice in each group. ${ }^{*} p<0.05$, ${ }^{* *} p<0.01$, and ${ }^{* * *} p<0.001$ versus control (untreated tumours). 

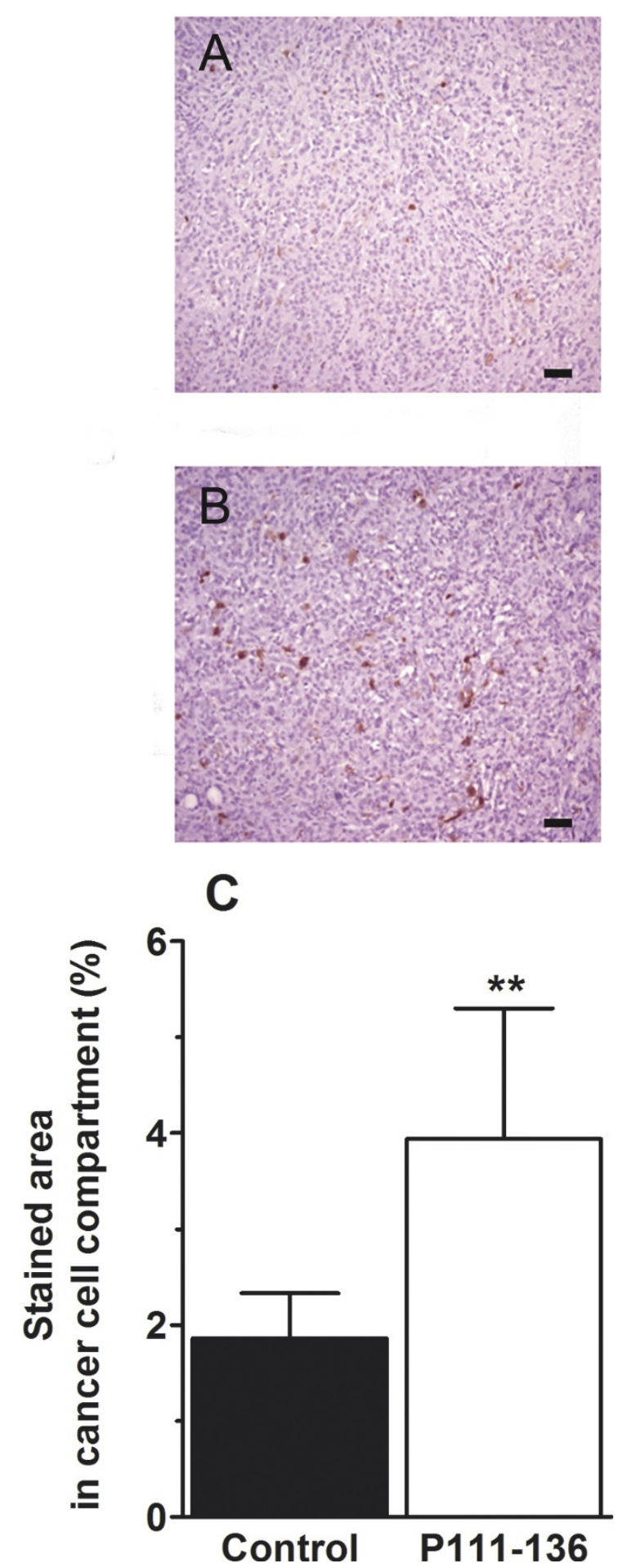

Figure 3 Induction of apoptosis in xenograft tumour by P111136. PC-3 tumour apoptosis was evaluated on tumour sections using immunohistochemistry with antibody directed against cleaved caspase 3. (A), untreated tumours and (B), tumours treated with P111-136. Scale bar, $100 \mu \mathrm{m}$. (C), apoptosis quantified by image analysis of caspase 3 -labelled cells on the whole tumour sections. The data are mean areas +/- SD obtained from 5 control mice and 5 mice treated with P111-136. ${ }^{* *} p<0.01$ versus control.
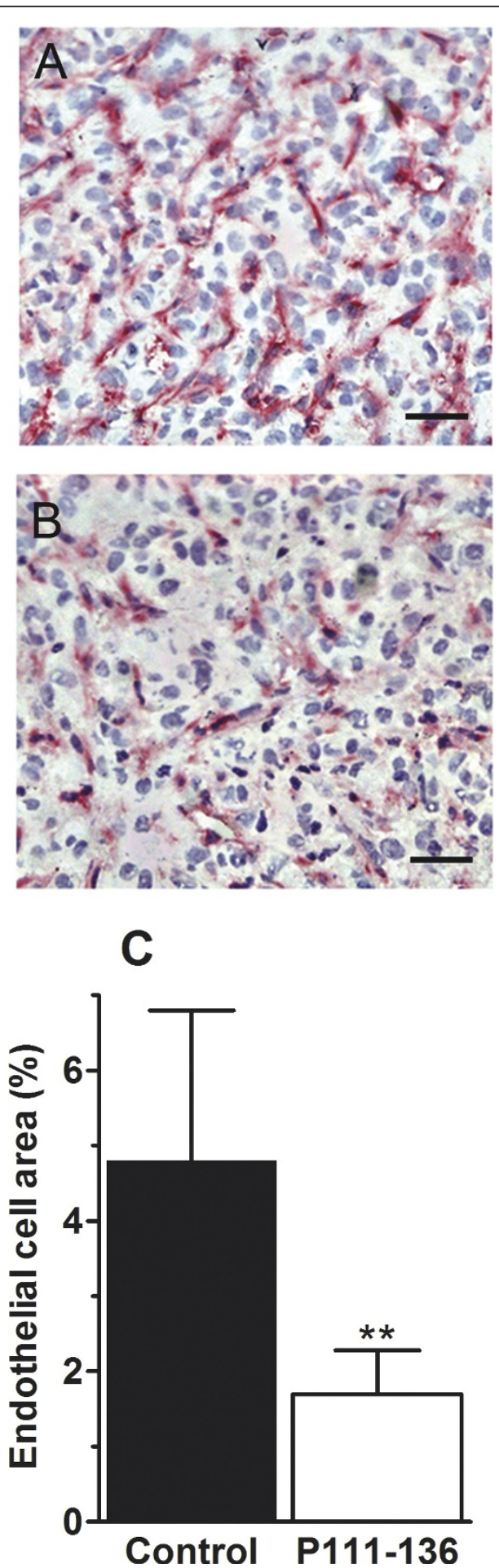

Figure 4 Inhibition of tumour angiogenesis by peptide P111136. For immunohistochemical analysis, tumour sections were prepared and stained with anti-CD31 antibodies. (A), untreated tumours and (B), tumours treated with P111-136. Scale bar, $100 \mu \mathrm{m}$. (C), angiogenesis was quantified by image analysis of CD31-labelled endothelial cells. The data are mean areas +/- SD obtained from 5 control mice and 5 mice treated with $\mathrm{P} 111-136 .{ }^{* *} p<0.01$ versus control. 


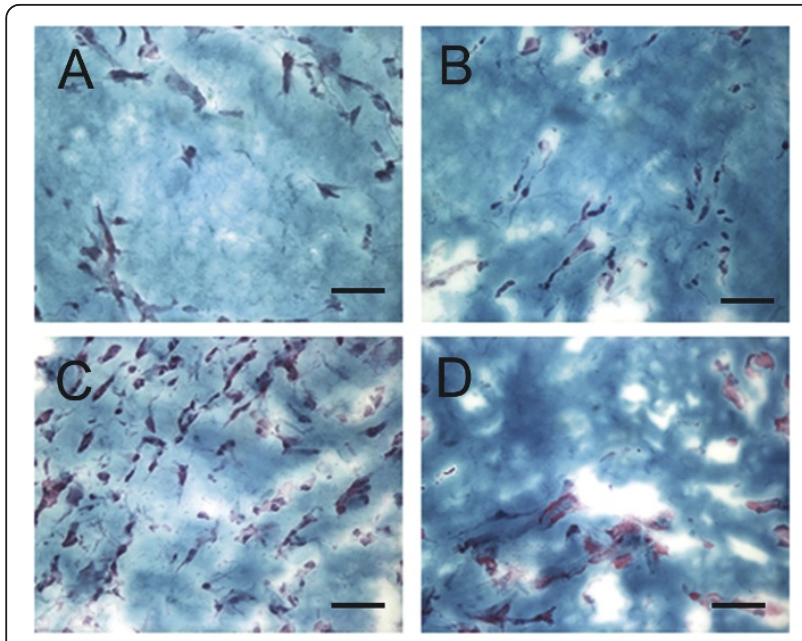

$E$

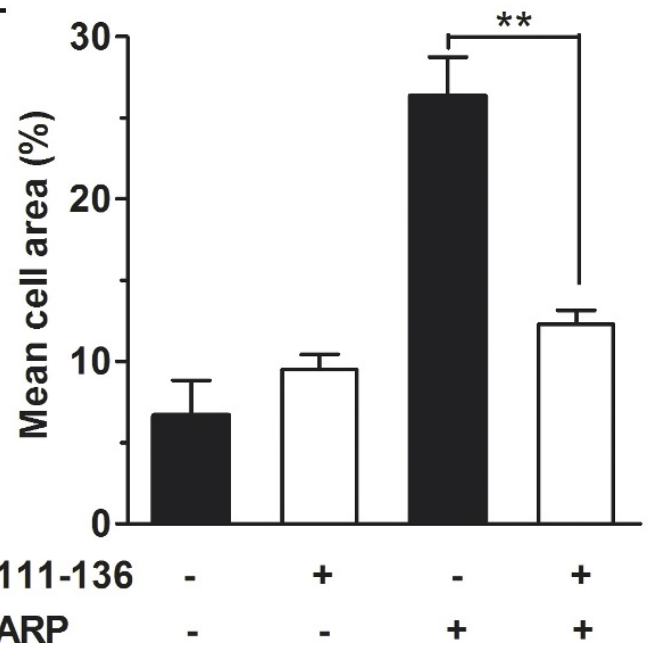

Figure 5 Inhibition of HARP-induced in vivo angiogenesis by peptide P111-136. Liquid Matrige ${ }^{\mathrm{TM}}$ at $4^{\circ} \mathrm{C}$ was injected subcutaneously into Swiss mice. The Matrige| ${ }^{\mathrm{TM}}$ was used alone or after incorporation of HARP, P111-136, or both. The animals were sacrificed 8 days later; the Matrige|TM plugs were removed, sectioned, stained using the Gomori-Trichrome method, and examined under the microscope. Scale bar, $100 \mu \mathrm{m}$. Micrographs of Gomori-Trichrome stained Matrigel ${ }^{\mathrm{TM}}$ plug (A) alone, (B) containing $1 \mu \mathrm{M}$ of P111-136, (C), containing $5 \mathrm{nM}$ of HARP, or (D) containing 5 nM of HARP and $1 \mu \mathrm{M}$ of P111-136. (E) endothelial-cell migration into the Matrige|TM was quantified as the mean cell count in six fields in each of three Matrige|TM plug sections per mouse, data are means + - SD of values in four mice per group. ${ }^{* *} p<0.01$.

(Figure 6B) and the $100 \mathrm{kDa}$ nucleolin and its degradation products (Figure 6C), as previously described [35]. For expression of ALK and RPTP $\beta / \zeta$, U87 MG and DU145 cell lysates were used respectively as control (Figure 6A and 6B). These different HARP interacting proteins were also detected in biot-P111-136 pull down experiments (Figure 6A, B and 6C) in which these proteins were identified by Western blot analysis while no band was detected when bio-P111-136 was omitted from the assay. It is noteworthy that only the $140 \mathrm{kDa}$ isoform of ALK was detected in the biot-P111-136 pull down (Figure 6A). All together these results demonstrate that the inhibition of $\mathrm{PC}-3$ proliferation observed with P111-136 could be link to a direct or indirect binding of this peptide to the different HARP interacting proteins.

\section{Discussion}

HARP is expressed in a wide range of tumour cell lines including neuroblastoma, glioblastoma, melanoma and also of cancers derived from the pancreas, breast, and prostate $[8,10,11,36-38]$. Numerous studies using ribozyme, RNA interference or antisense strategies [12,38-41] showed that HARP was a potential in vivo rate-limiting angiogenic factor in tumour growth and metastasis. As a result, HARP and its two signalling receptors ALK and RPTP $\beta / \zeta$ are now viewed as promising targets for cancer therapy $[17,38,39,42,43]$. Using recombinant deletion mutant of HARP, we previously established that the HARP C-terminus domain, composed of amino acids 111 to 136, was closely involved in the mitogenic, angiogenic and transforming activities of HARP $[25,26]$. Thus, the synthetic peptide P111-136 has been shown to bind to the ALK receptor, thereby acting as a dominant inhibitor of the biological activities of HARP. These findings, together with the key role for HARP in prostate-tumour growth, prompted us to further investigate the potential anti-tumour effects of P111-136, using the human androgen-independent adenocarcinoma PC-3 cell line, which expressed HARP and its receptors [11].

In the in vitro experiments reported here, P111-136 inhibited the growth of PC-3 cells. Using whole-cell lysate from PC-3 cells, pull-down experiments with biotinylated P111-136 indicated that P111-136 interact, as expected, with ALK and also with $\mathrm{RPTP} \beta / \zeta$ suggesting that this peptide might bind also to the RPTP $\beta / \zeta$ receptor. This hypothesis is strengthen by the recent data showing that synthetic peptide including amino acids 122 to 131 derived from the C-terminus region of HARP binds to RPTP $\beta / \zeta$ [29]. Recently Diamantopoulou et al [33] have demonstrated that this shorter peptide P122-131 was able to inhibit the proliferation of other human prostate cancer cell lines DU145 and LNCaP. It is interesting to mention that these cell lines do not express the ALK receptor (Additional file 1, Figure S1). However, when tested in our conditions, P122-131 inhibited only the anchorage independent growth of PC3 cells by $22 \%$ at $1 \mu \mathrm{M}$ when compare to $47 \%$ for P111136. The presence of the ALK receptor in PC-3 cells could explain this difference of efficiency between the two peptides but further investigations of both peptides 

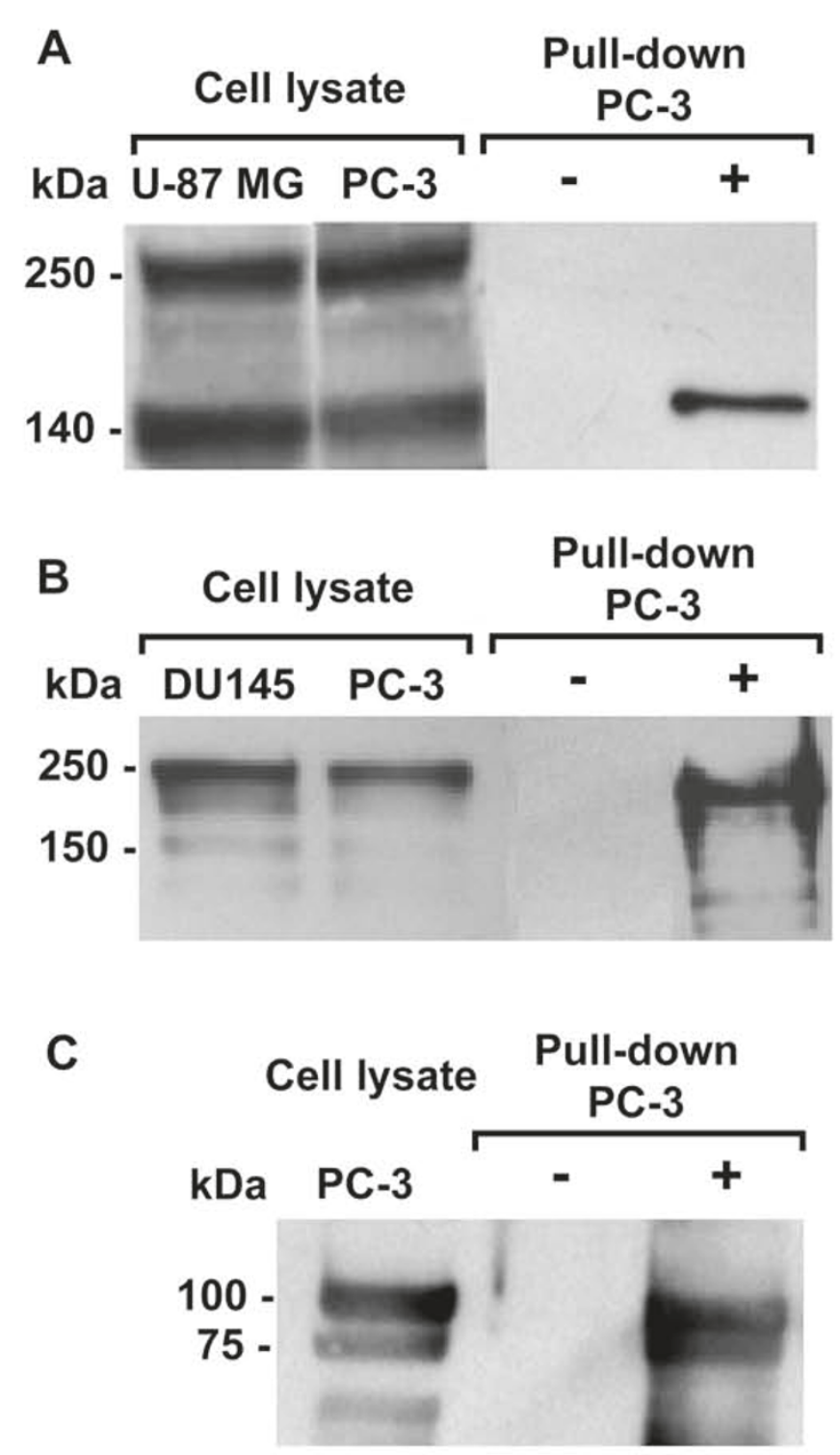

Figure 6 Interaction of P111-136 with HARP receptors. Whole PC-3 cell lysates were incubated or not with biot-P111-136 immobilized on streptavidin-Sepharose beads, or with streptavidin-Sepharose beads alone. The lysates or the precipitates were analyzed by SDS-PAGE and electroblotted and the membrane was probed against ALK (A), RPTP $\beta / \zeta$ (B) and nucleolin (C) using specific antibodies. U87 MG and DU145 cell lysates were respectively used as positive controls for the presence of ALK and RPTP $\beta / \zeta$ receptors.

on these different prostate cancer cell lines will be need to clarify this point. When assayed on the human glioblastoma cell line U87 MG described previously as expressing a low level of RPTP $\beta / \zeta$ [44], P111-136 inhibited the colony formation in a lesser extent (data not shown) supposing that an optimal expression of both ALK and RPTP $/ \zeta$ receptors could be important for a strong effect of P111-136. Therefore, further investigations will be needed to verify this assumption. For several years, the receptors involved in the growthpromoting effect of HARP are a matter of controversy
[45] due to the cell system and molecular tools used. However, it has been clearly demonstrated that the binding of HARP or its related protein MK to the ALK receptor activated the intracellular kinase domain and further stimulated the downstream MAP and PI-3 kinase pathways $[13,46,47]$. More, recently Stylianou et al., have also mapped the HARP ligand binding domain on ALK and found that a single chain antibody was able to compete for the HARP binding and inhibit its intercellular downstream signal [48]. Other data have reported that binding of HARP to RPTP $\beta / \zeta$ receptor 
oligomerised the receptor and inactivated its intracellular catalytic phosphatase activity, leading to further activation of the Src/Fyn kinase family and $\beta$-catenin phosphorylation pathway $[20,21]$. The RPTP $\beta / \zeta$ receptor was found to be involved in HARP-induced cell migration and neurite outgrowth $[18,19]$ and was then shown to play a role in glioblastoma cell proliferation $[42,43]$. In addition, a recent study $[24,42,43]$ identified an alternative mechanism in which binding of HARP to RPTP $\beta / \zeta$ maintained the phosphorylation of ALK, leading to further activation of its pathway. The results described in this study, strongly suggested that a link between ALK and RPTP $\beta / \zeta$ could occur in PC-3 cells since P111-136 pulled down both receptors.

Nucleolin, a nuclear and cytoplasmic protein initially related to rRNA maturation ribosome assembly [49], was also described as a cell surface protein [35] and as a low affinity binding protein for HARP [34] and MK $[50,51]$. Since nucleolin was clearly identified in our pull down experiments, it is tempting to suggest that this protein could also be implicated in the HARP biological activities. As support of this hypothesis, we have shown that anti nucleolin antibody inhibited the biological activity of HARP in MDA-MB 231 cell line [52]. The mechanism of this inhibition remains to be studied. However, previous data have shown that the $\beta$-sheet domains of HARP, especially those located on the Cterminal part of the molecule, were involved in the binding of HARP to nucleolin. Since nucleolin was pulled down by P111-136 in our experiments, we could speculate that the peptide did not bind directly to nucleolin but through other non identified molecules, this possibility is currently under evaluation.

The strong inhibition of P111-136 observed on the growth of PC-3 cells in vitro and their tumour xenograft in nude mice could be explain because it targets directly or indirectly different proteins of the HARP pathway. Furthermore in vivo, the inhibition of tumour growth was linked with an increase in PC-3 cells apoptosis and a decreased in the tumour associated angiogenesis. During this treatment, no side effects were observed on mice suggesting that P111-136 did not present any toxicity nor cause additional pathology on animals. Recently Grzelinski et al., [53] have demonstrated an enhanced antitumor effect on glioblastoma using a double ribozyme strategy targeting HARP and one of its receptor. It is tempting to speculate that such results could be obtained on PC-3 tumours in combining P111-136 treatment with another molecule that target the HARP pathway.

Evidence that $\mathrm{C}$-terminus maturation influences the biological effects of HARP was obtained in an earlier study, in which a $14-\mathrm{kDa}$ C-terminal truncated form of HARP influenced the proliferation of cells like bovine epithelial lens cells [54]. Thus, natural processing of the HARP molecule could be pivotal in regulating the biodistribution and biological effects of HARP in health and disease. In keeping with this possibility, we showed that plasmin and MMP-2 cleaved HARP in vitro, releasing various peptides that may differentially affect the angiogenic and mitogenic activities of HARP $[55,56]$. GAGs in the microenvironment may protect HARP from this enzymatic cleaving. Thus, the biological effect of HARP is the net result not only of HARP secretion and degradation, but also of specific enzymatic processing, which depends on the proteases and GAGs present in the microenvironment and may generate peptides that have diverse (and perhaps opposite) biological effects.

\section{Conclusions}

Our results demonstrate that P111-136 strongly inhibits the proliferative effect of HARP on in vitro and in vivo growth of PC-3 cells. This inhibition of P111-136 could be link to a direct or indirect binding of this peptide to the different HARP interacting proteins (ALK, RPTP $\beta / \zeta$, nucleolin). In vivo, the daily P111-136 treatment was as effective as the one of a clinical drug used in prostate cancer therapy. Furthermore the tumour growth inhibition was associated with an inhibition of angiogenesis and an increase in PC-3 cells apoptosis. Thus, P111-136 may be considered as an interesting pharmacological tool to interfere with tumour growth that has now to be evaluated in other cancer types and animals models.

\section{Additional material}

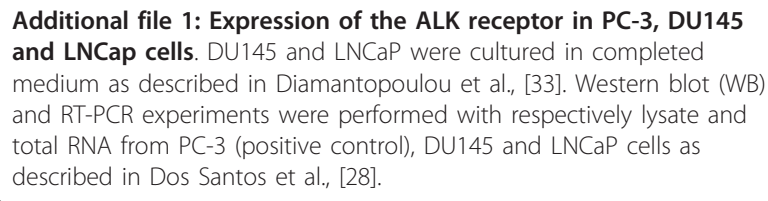

\section{List of abbreviations}

HARP: heparin affin regulatory peptide; DMEM: Dulbecco's modified Eagle medium; PBS: phosphate buffer saline; ALK: anaplastic lymphoma kinase; RPTP $\beta / \zeta$ (Receptor Protein Tyrosine Phosphatase $\beta / \zeta$ );

\section{Acknowledgements}

Authors want to thank G. Carpentier at Université Paris Est Créteil and Dr P. Opolon at Institut Gustave Roussy for image analysis of tumour sections. Authors want also to thank E. Gobbo and V. Rouet for their valuable technical help. Racha Karaky was funded by the French Ministère délégué à l'enseignement supérieur et à la recherche.

This work was supported by grant 06-RIB-016-02 from the French Agence National de la Recherche, grant PL06-093 from the French Institut National du Cancer, and grant 3242 from Association pour la Recherche sur le Cancer.

\section{Author details}

'Laboratoire de Recherche sur la Croissance Cellulaire, la Réparation et la Régénération Tissulaires (CRRET), Université Paris Est Créteil, CNRS, avenue du 
Général de Gaulle, 94010 Créteil Cedex, France. ${ }^{2}$ CNRS, Vectorologie et Transfert de Gènes, Institut Gustave Roussy PR2, 38 rue Camille Desmoulins 94805 Villejuif Cedex, France. ${ }^{3}$ The present address of I. Bernard-Pierrot is UMR 144, CNRS-Institut Curie, 26 rue d'Ulm, 75248 Paris Cedex 05, France.

\section{Authors' contributions}

YHK was the major contributor of this work in designing, executing experiments, interpreting the results and contributing to drafting the manuscript. $\mathrm{OB}$ contributed to experiments and participated in interpretation of the results. IBP contributed to the development of this study and to the first experiments. RK and SF provided assistance to YHK and $\mathrm{OB}$ for the experiments. DRM contributed to analysis, interpretation of the results and was involved in revising the manuscript. JC and JD were responsible for this study, participating in the design, the analysis, and the interpretation of the results, drafting and overseeing all stages of the revision of the manuscript. All authors read and approved the final manuscript.

\section{Competing interests}

The authors declare that they have no competing interests.

Received: 4 February 2011 Accepted: 30 May 2011

Published: 30 May 2011

\section{References}

1. Cunha GR, Donjacour A: Stromal-epithelial interactions in normal and abnormal prostatic development. Prog Clin Biol Res 1987, 239:251-272.

2. Courty J, Milhiet PE, Delbe J, Caruelle D, Barritault D: Heparin-Affin Regulatory Peptide, HARP. Springer 2000.

3. Russell PJ, Bennett S, Stricker P: Growth factor involvement in progression of prostate cancer. Clin Chem 1998, 44(4):705-723.

4. Muramatsu T: Midkine and pleiotrophin: two related proteins involved in development, survival, inflammation and tumorigenesis. J Biochem (Tokyo) 2002, 132(3):359-371.

5. Pufe T, Bartscher M, Petersen W, Tillmann B, Mentlein R: Expression of pleiotrophin, an embryonic growth and differentiation factor, in rheumatoid arthritis. Arthritis Rheum 2003, 48(3):660-667.

6. Heroult M, Bernard-Pierrot I, Delbe J, Hamma-Kourbali Y, Katsoris $P$, Barritault D, Papadimitriou E, Plouet J, Courty J: Heparin affin regulatory peptide binds to vascular endothelial growth factor (VEGF) and inhibits VEGF-induced angiogenesis. Oncogene 2004, 23(9):1745-1753.

7. Chauhan AK, Li YS, Deuel TF: Pleiotrophin transforms NIH 3 T3 cells and induces tumors in nude mice. Proceedings of the National Academy of Sciences of the United States of America 1993, 90(2):679-682.

8. Fang W, Hartmann N, Chow DT, Riegel AT, Wellstein A: Pleiotrophin stimulates fibroblasts and endothelial and epithelial cells and is expressed in human cancer. Journal of Biological Chemistry 1992, 267(36):25889-25897.

9. Soulie P, Heroult M, Bernard-Pierrot I, Caruelle D, Oglobine J, Barritault D, Courty J: Correlation of elevated plasma levels of two structurally related growth factors, heparin affin regulatory peptide and midkine, in advanced solid tumor patients. Cancer Detect Prev 2004, 28(5):319-324.

10. Souttou B, Juhl H, Hackenbruck J, Rockseisen M, Klomp HJ, Raulais D, Vigny M, Wellstein A: Relationship between serum concentrations of the growth factor pleiotrophin and pleiotrophin-positive tumors. J Natl Cancer Inst 1998, 90(19):1468-1473.

11. Vacherot F, Caruelle D, Chopin D, Gil-Diez S, Barritault D, Caruelle JP, Courty J: Involvement of heparin affin regulatory peptide in human prostate cancer. Prostate 1999, 38(2):126-136.

12. Hatziapostolou M, Delbe J, Katsoris P, Polytarchou C, Courty J, Papadimitriou E: Heparin affin regulatory peptide is a key player in prostate cancer cell growth and angiogenicity. Prostate 2005, 65(2):151-158.

13. Stoica GE, Kuo A, Aigner A, Sunitha I, Souttou B, Malerczyk C, Caughey DJ, Wen D, Karavanov A, Riegel AT, et al: Identification of anaplastic lymphoma kinase as a receptor for the growth factor pleiotrophin. J Biol Chem 2001, 276(20):16772-16779.

14. Morris SW, Kirstein MN, Valentine MB, Dittmer KG, Shapiro DN, Saltman DL, Look AT: Fusion of a kinase gene, ALK, to a nucleolar protein gene, NPM, in non-Hodgkin's lymphoma. Science 1994, 263(5151):1281-1284.
15. Iwahara T, Fujimoto J, Wen D, Cupples R, Bucay N, Arakawa T, Mori S, Ratzkin B, Yamamoto T: Molecular characterization of ALK, a receptor tyrosine kinase expressed specifically in the nervous system. Oncogene 1997, 14(4):439-449.

16. Peria FM, Neder L, Marie SK, Rosemberg S, Oba-Shinjo SM, Colli BO, Gabbai AA, Malheiros SM, Zago MA, Panepucci RA, et al: Pleiotrophin expression in astrocytic and oligodendroglial tumors and it's correlation with histological diagnosis, microvascular density, cellular proliferation and overall survival. J Neurooncol 2007, 84(3):255-261.

17. Powers C, Aigner A, Stoica GE, McDonnell K, Wellstein A: Pleiotrophin signaling through anaplastic lymphoma kinase (ALK) is rate- limiting for glioblastoma growth. J Biol Chem 2002, 23:23.

18. Maeda N, Noda M: Involvement of receptor-like protein tyrosine phosphatase zeta/RPTP beta and its ligand pleiotrophin/heparin-binding growth-associated molecule (HB-GAM) in neuronal migration. J Cell Biol 1998, 142(1):203-216

19. Polykratis A, Katsoris P, Courty J, Papadimitriou E: Characterization of heparin affin regulatory peptide signaling in human endothelial cells. $J$ Biol Chem 2005, 280(23):22454-22461.

20. Meng K, Rodriguez-Pena A, Dimitrov T, Chen W, Yamin M, Noda M, Deuel TF: Pleiotrophin signals increased tyrosine phosphorylation of beta beta-catenin through inactivation of the intrinsic catalytic activity of the receptor-type protein tyrosine phosphatase beta/zeta. Proc Natl Acad Sci USA 2000, 97(6):2603-2608.

21. Pariser H, Ezquerra L, Herradon G, Perez-Pinera P, Deuel TF: Fyn is a downstream target of the pleiotrophin/receptor protein tyrosine phosphatase beta/zeta-signaling pathway: regulation of tyrosine phosphorylation of Fyn by pleiotrophin. Biochem Biophys Res Commun 2005, 332(3):664-669.

22. Pariser H, Herradon G, Ezquerra L, Perez-Pinera P, Deuel TF: Pleiotrophin regulates serine phosphorylation and the cellular distribution of betaadducin through activation of protein kinase C. Proc Natl Acad Sci USA 2005, 102(35):12407-12412.

23. Tamura H, Fukada M, Fujikawa A, Noda M: Protein tyrosine phosphatase receptor type $Z$ is involved in hippocampus-dependent memory formation through dephosphorylation at Y1105 on p190 RhoGAP. Neurosci Lett 2006, 399(1-2):33-38

24. Perez-Pinera P, Zhang W, Chang Y, Vega JA, Deuel TF: Anaplastic Lymphoma Kinase Is Activated Through the Pleiotrophin/Receptor Protein-tyrosine Phosphatase beta/\{zeta\} Signaling Pathway: An Alternative Mechanism Of Receptor Tyrosine Kinase Activation. J Biol Chem 2007, 282(39):28683-28690.

25. Bernard-Pierrot I, Delbe J, Caruelle D, Barritault D, Courty J, Milhiet PE: The lysine-rich C-terminal tail of heparin affin regulatory peptide is required for mitogenic and tumor formation activities. J Biol Chem 2001 276(15):12228-12234

26. Bernard-Pierrot I, Delbe J, Rouet V, Vigny M, Kerros ME, Caruelle D, Raulais D, Barritault D, Courty J, Milhiet PE: Dominant negative effectors of heparin affin regulatory peptide (HARP) angiogenic and transforming activities. J Biol Chem 2002, 277(35):32071-32077.

27. Hamma-Kourbali Y, Bernard-Pierrot I, Heroult M, Dalle S, Caruelle D, Milhiet PE, Fernig DG, Delbe J, Courty J: Inhibition of the mitogenic, angiogenic and tumorigenic activities of pleiotrophin by a synthetic peptide corresponding to its C-thrombospondin repeat-I domain. J Cell Physiol 2008, 214(1):250-259.

28. Dos Santos C, Karaky R, Renoir D, Hamma-Kourbali Y, Albanese P, Gobbo E, Griscelli F, Opolon P, Dalle S, Perricaudet M, et al: Antitumorigenic effects of a mutant of the heparin affin regulatory peptide on the U87 MG glioblastoma cell line. Int I Cancer 2010, 127(5):1038-1051.

29. Bermek O, Diamantopoulou Z, Polykratis A, Dos Santos C, HammaKourbali Y, Burlina F, Delbe J, Chassaing G, Fernig DG, Katsoris P, et al: A basic peptide derived from the HARP C-terminus inhibits anchorageindependent growth of DU145 prostate cancer cells. Exp Cell Res 2007, 313(19):4041-4050

30. Martel-Renoir D, Trochon-Joseph V, Galaup A, Bouquet C, Griscelli F, Opolon P, Opolon D, Connault E, Mir L, Perricaudet M: Coelectrotransfer to skeletal muscle of three plasmids coding for antiangiogenic factors and regulatory factors of the tetracycline-inducible system: tightly regulated expression, inhibition of transplanted tumor growth, and antimetastatic effect. Mol Ther 2003, 8(3):425-433. 
31. Elie N, Plancoulaine B, Signolle JP, Herlin P: A simple way of quantifying immunostained cell nuclei on the whole histologic section. Cytometry $A$ 2003, 56(1):37-45

32. Soulie P, Heroult M, Bernard I, Kerros ME, Milhiet PE, Delbe J, Barritault D, Caruelle D, Courty J: Immunoassay for measuring the heparin-binding growth factors HARP and MK in biological fluids. J Immunoassay Immunochem 2002, 23(1):33-48.

33. Diamantopoulou Z, Bermek O, Polykratis A, Hamma-Kourbali Y, Delbe J, Courty J, Katsoris P: A Pleiotrophin C-terminus peptide induces anticancer effects through RPTPbeta/zeta. Mol Cancer 2010, 9:224.

34. Said EA, Courty J, Svab J, Delbe J, Krust B, Hovanessian AG: Pleiotrophin inhibits HIV infection by binding the cell surface-expressed nucleolin. Febs J 2005, 272(18):4646-4659.

35. Christian S, Pilch J, Akerman ME, Porkka K, Laakkonen P, Ruoslahti E: Nucleolin expressed at the cell surface is a marker of endothelial cells in angiogenic blood vessels. J Cell Biol 2003, 163(4):871-878.

36. Choudhuri R, Zhang HT, Donnini S, Ziche M, Bicknell R: An angiogenic role for the neurokines midkine and pleiotrophin in tumorigenesis. Cancer Res 1997, 57(9):1814-1819.

37. Jager R, Noll K, Havemann K, Knabbe C, Rauvala H, Zugmaier G: Differential expression and biological activity of the heparin-binding growthassociated molecule (HB-GAM) in lung cancer cell lines. Int J Cancer 1997 73:537-543.

38. Weber D, Klomp HJ, Czubayko F, Wellstein A, Juhl H: Pleiotrophin can be rate-limiting for pancreatic cancer cell growth. Cancer Res 2000, 60(18):5284-5288.

39. Czubayko F, Riegel AT, Wellstein A: Ribozyme-targeting elucidates a direct role of pleiotrophin in tumor growth. J Biol Chem 1994, 269(33):21358-21363.

40. Czubayko F, Schulte AM, Berchem GJ, Wellstein A: Melanoma angiogenesis and metastasis modulated by ribozyme targeting of the secreted growth factor pleiotrophin. Proceedings of the National Academy of Sciences of the United States of America 1996, 93(25):14753-14758.

41. Grzelinski M, Urban-Klein B, Martens T, Lamszus K, Bakowsky U, Hobel S, Czubayko F, Aigner A: RNA interference-mediated gene silencing of pleiotrophin through polyethylenimine-complexed small interfering RNAs in vivo exerts antitumoral effects in glioblastoma xenografts. Hum Gene Ther 2006, 17(7):751-766.

42. Foehr ED, Lorente G, Kuo J, Ram R, Nikolich K, Urfer R: Targeting of the receptor protein tyrosine phosphatase beta with a monoclonal antibody delays tumor growth in a glioblastoma model. Cancer Res 2006, 66(4):2271-2278

43. Ulbricht U, Eckerich C, Fillbrandt R, Westphal M, Lamszus K: RNA interference targeting protein tyrosine phosphatase zeta/receptor-type protein tyrosine phosphatase beta suppresses glioblastoma growth in vitro and in vivo. J Neurochem 2006, 98(5):1497-1506.

44. Lu KV, Jong KA, Kim GY, Singh J, Dia EQ, Yoshimoto K, Wang MY, Cloughesy TF, Nelson SF, Mischel PS: Differential induction of glioblastoma migration and growth by two forms of pleiotrophin. J Biol Chem 2005, 280(29):26953-26964.

45. Mathivet $T$, Mazot $P$, Vigny $M$ : In contrast to agonist monoclonal antibodies, both C-terminal truncated form and full length form of Pleiotrophin failed to activate vertebrate ALK (anaplastic lymphoma kinase)? (ell Signal 2007, 19(12):2434-2443.

46. Bowden ET, Stoica GE, Wellstein A: Anti-apoptotic signaling of pleiotrophin through its receptor, anaplastic lymphoma kinase. J Biol Chem 2002, 277(39):35862-35868.

47. Stoica GE, Kuo A, Powers C, Bowden ET, Sale EB, Riegel AT, Wellstein A: Midkine binds to anaplastic lymphoma kinase (ALK) and acts as a growth factor for different cell types. J Biol Chem 2002, 277(39):35990-35998.

48. Stylianou DC, Auf der Maur A, Kodack DP, Henke RT, Hohn S, Toretsky JA, Riegel AT, Wellstein A: Effect of single-chain antibody targeting of the ligand-binding domain in the anaplastic lymphoma kinase receptor. Oncogene 2009, 28(37):3296-3306.

49. Ginisty $H$, Sicard $H$, Roger $B$, Bouvet $P$ : Structure and functions of nucleolin. J Cell Sci 1999, 112(Pt 6):761-772.

50. Shibata $Y$, Muramatsu T, Hirai M, Inui T, Kimura T, Saito H, McCormick LM, $\mathrm{Bu} \mathrm{G}$, Kadomatsu K: Nuclear targeting by the growth factor midkine. Mol Cell Biol 2002, 22(19):6788-6796.
51. Take M, Tsutsui J, Obama H, Ozawa M, Nakayama T, Maruyama I, Arima T, Muramatsu T: Identification of nucleolin as a binding protein for midkine (MK) and heparin-binding growth associated molecule (HB-GAM). Journal of Biochemistry 1994, 116(5):1063-1068.

52. Destouches D, El Khoury D, Hamma-Kourbali Y, Krust B, Albanese $P$ Katsoris P, Guichard G, Briand JP, Courty J, Hovanessian AG: Suppression of tumor growth and angiogenesis by a specific antagonist of the cellsurface expressed nucleolin. PLoS One 2008, 3(6):e2518.

53. Grzelinski M, Steinberg F, Martens T, Czubayko F, Lamszus K, Aigner A: Enhanced antitumorigenic effects in glioblastoma on double targeting of pleiotrophin and its receptor ALK. Neoplasia 2009, 11(2):145-156.

54. Souttou B, Ahmad S, Riegel AT, Wellstein A: Signal transduction pathways involved in the mitogenic activity of pleiotrophin - Implication of mitogen-activated protein kinase and phosphoinositide 3-kinase pathways. J Biol Chem 1997, 272(31):19588-19593.

55. Dean RA, Butler GS, Hamma-Kourbali Y, Delbe J, Brigstock DR, Courty J, Overall CM: Identification of candidate angiogenic inhibitors processed by matrix metalloproteinase 2 (MMP-2) in cell-based proteomic screens: disruption of vascular endothelial growth factor (VEGF)/heparin affin regulatory peptide (pleiotrophin) and VEGF/Connective tissue growth factor angiogenic inhibitory complexes by MMP-2 proteolysis. Mol Cell Biol 2007, 27(24):8454-8465.

56. Polykratis A, Delbe J, Courty J, Papadimitriou E, Katsoris P: Identification of heparin affin regulatory peptide domains with potential role on angiogenesis. Int J Biochem Cell Biol 2004, 36(10):1954-1966.

\section{Pre-publication history}

The pre-publication history for this paper can be accessed here: http://www.biomedcentral.com/1471-2407/11/212/prepub

\section{doi:10.1186/1471-2407-11-212}

Cite this article as: Hamma-Kourbali et al:: The synthetic peptide P111136 derived from the $\mathrm{C}$-terminal domain of heparin affin regulatory peptide inhibits tumour growth of prostate cancer PC-3 cells. BMC Cancer 2011 11:212.

\section{Submit your next manuscript to BioMed Central and take full advantage of:}

- Convenient online submission

- Thorough peer review

- No space constraints or color figure charges

- Immediate publication on acceptance

- Inclusion in PubMed, CAS, Scopus and Google Scholar

- Research which is freely available for redistribution

Submit your manuscript at www.biomedcentral.com/submit
C) Biomed Central 